\title{
POTENSI BUNGA MARIGOLD (Tagetes erecta L.) SEBAGAI SALAH SATU KOMPONEN PENDUKUNG PENGEMBANGAN PERTANIAN
}

\section{THE POTENCY OF MARIGOLD FLOWERS (Tagetes erecta L.) AS ONE OF THE SUPPORTING COMPONENTS OF AGRICULTURAL DEVELOPMENT}

\author{
Fitri Kurniati \\ Program Studi Agroteknologi Fakultas Pertanian Universitas Siliwangi \\ Jalan Siliwangi No. 24 Kota Tasikmalaya \\ Korespondensi : fitri.kurniati61@gmail.com
}

\begin{abstract}
ABSTRAK
Marigold (Tagetes $s p$ ) merupakan tanaman hias yang sudah dikenal sejak lama di Indonesia, namun hanya di beberapa daerah yang menggunakannya secara rutin pada upacara keagamaan dan digunakan untuk bunga papan. Temuan peneliti baik di dalam maupun luar negeri menunjukkan bahwa bunga ini mempunyai potensi untuk dikembangkan karena banyak sekali kegunaannya. Berdasarkan hal tersebut artikel ini dibuat dengan tujuan memperluas penyebaran informasi dan meningkatkan animo untuk menelaah tentang marigold. Metode yang digunakan untuk membuat artikel ini adalah studi literatur dari berbagai telaahan dan hasil penelitian. Pada dasarnya kegunaan yang diperoleh dari bunga marigold disebabkan pada bunga marigold terkandung karotenoid berwarna kuning seperti karoten yaitu alfa dan beta karoten dan xantofil yaitu lutein dan zeaxantin, selain itu terkandung flavonoid. Karotenoid bisa menjadi antioksidan, menyembuhkan demam ringan, sakit tenggorokan ringan, pelembab alami, dan pengusir nyamuk alami. Flavonoid adalah metabolit sekunder dari polifenol yang memiliki berbagai efek bioaktif termasuk anti virus, anti-inflamasi, anti penuaan, antioksidan, kardioprotektif, antidiabetes, dan anti kanker. Dengan demikian, bunga marigold bisa digunakan sebagai obat herbal, refugia, dan bahan obat anti nyamuk. Faktor pendukung yang pengembangan adalah: marigold mudah dibudidayakan, secara ekonomis dan ekologis menguntungkan. Maka, marigold bisa dijadikan ladang usaha rumahan maupun skala besar.
\end{abstract}

Kata kunci: Flavonoid, Karotenoid, Marigold, Refugia

\begin{abstract}
Marigold (Tagetes $s p$ ) is an ornamental plant that has been known for a long time in Indonesia, but has not attracted to be developed massively except in some areas that use it regularly at religious ceremonies and used for flower boards. The findings of researchers both in Indonesia and another country show that this flower has the potential to be developed because of its many uses. Based on this article was created with the aim of expanding the dissemination of information and increasing animo to study about marigolds. The method used to create this article is the study of literature from various studies and research results. Basically the use obtained from marigold flowers is caused in marigold flowers contained yellow carotenoids such as carotene i.e. alpha and beta carotene and xantofil namely lutein and zeaxantin, in addition contained flavonoids. Carotenoids can be antioxidants, curing mild fever, mild sore throats, natural moisturizers, and natural mosquito repellents. Flavonoids are secondary
\end{abstract}


metabolites of polyphenols that have a variety of bioactive effects including anti-viral, antiinflammatory, anti-aging, antioxidant, cardioprotective, antidiabetic, and anti-cancer. Thus, in addition to garden decorative flowers, board flowers, marigold flowers can be used as herbal remedies, refugia, and mosquito repellent ingredients. Supporting factors for development are: marigold plants are easy to cultivate, economically and ecologically profitable. Therefore marigolds can be used as home-scale business fields as well as large scale.

Keywords : Flavonoid, Carotenoid, Marigold, Refugia

\section{PENDAHULUAN}

Marigold (Tagetes sp) disebut juga gemitir (Bali), merupakan salah satu tanaman hias jenis kenikir yang potensial untuk dikembangkan karena banyak kegunaannya. Selain sebagai bunga hias, pada sektor kuliner marigold dapat dijadikan sebagai bahan pewarna alami dan hiasan, pada sektor pertanian dapat berfungsi sebagai agen hayati untuk penarik predator hama, penghias taman pada sektor pariwisata. Pada sektor kesehatan bunga marigold berfungsi sebagai antioksidan, anti bakteri, anti inflamasi, dan anti karsinogen (Wahyu, 2019). Dikatakan pula oleh Zahir (2021), bahwa marigold mengandung karotenoid yang bisa menjadi antioksidan, menyembuhkan demam ringan, sakit tenggorokan ringan, pelembab alami, dan pengusir nyamuk alami.

Tanaman kenikir banyak diteliti di luar negeri karena bunganya merupakan sumber pigmen karotenoid berwarna kuning seperti karoten yaitu alfa dan beta karoten dan xantofil yaitu lutein dan zeaxantin (Handelman, 2001). Warna kuning bunga kenikir disebabkan oleh dua pigmen utama, yaitu pigmen dari golongan karotenoid dan flavonoid. Ekstrak bunga kenikir mengandung sekitar $27 \%$ pigmen karotenoid dan khusus untuk mahkota kenikir mengandung karotenoid sekitar 200 kali lebih besar dari karotenoid yang dikandung oleh jagung (Seafast Center, 2012).
Di Indonesia bunga marigold sudah lama dikenal. Namun demikian belum dikembangkan secara besar-besaran, dan bukan merupakan bunga unggulan seperti anggrek, krisan, melati, raphis, heliconia, leather leaf, mawar dan lain-lain.

Sentra tanaman marigold di Indonesia, adalah di beberapa kabupaten di Propinsi Bali seperti Kecamatan Petang Kabupaten Badung, Kecamatan Baturiti Kabupaten Tabanan, Kecamatan Kintamani (Setiawan, 2017 ; Nata, Dharma, dan Wijaya, 2020).

Di Bali, bunga ini sudah sangat familiar karena biasa digunakan sebagai bunga utama pada acara-acara keagamaan dan sesaji harian (Beti, 2020). Industri bunga marigold di Bali diperkirakan mencapai 100-200 milyar rupiah per tahun dengan kebutuhan bunga 8 ton per hari. Di daerah Bandungan, Kabupaten Semarang dan dataran tinggi lainnya, marigold banyak dibudidayakan secara komersial untuk tujuan produksi bunga, benih, maupun sebagai bunga background selfi pada lokasi wisata bunga. Di pasar induk tanaman hias di Bandungan bunga marigold banyak diperjual belikan terutama untuk bahan rangkaian bunga papan (Beti, 2020).

Kebutuhan akan bunga ini di Indonesia mencapai 40 ton hari $^{-1}$. Oleh karena itu bunga ini akan menjadi salah satu tanaman hias unggulan dan memiliki nilai ekonomis yang tinggi (Wahyu, 2019).

Di tingkat internasional, Negara India merupakan eksportir bunga marigold untuk tujuan beberapa negara di Asia, seperti Singapura, Vietnam, Korea, Hongkong, 
UEA dan ke negara non Asia seperti USA, Canada, dan Jerman (Priyanka et al., 2013 dalam Beti, 2020). India memang merupakan pengguna sekaligus penghasil bunga Marigold yang cukup besar. Salah satunya adalah di Jammu City dan Kashmir, India. Jammu merupakan Negara bagian yang memerlukan marigold sepanjang tahun terutama untuk acara keagamaan (Kumar et al., 2020).

Potensi pasar ke negara-negara lain sangat besar terutama negara yang banyak menggunakan bunga marigold untuk upacara keagamaan, atau menggunakan minyak atsiri marigold untuk obat nyamuk dan insektisida nabati, sebagai pewarna alami, untuk bahan pangan maupun pakan. Sekaitan dengan hal tersebut, Indonesia dapat mengambil peluang sebagai eksportir karena mempunyai beberapa faktor pendukung, yaitu kesesuaian iklim sebagai daerah tropis, tanah yang luas dan subur, dan faktor kedekatan jarak ke negara pengimpor seperti Singapura dan Vietnam (Beti, 2020). Dengan demikian, selain untuk memenuhi kebutuhan dalam negeri, produksi dapat ditingkatkan untuk menembus peluang ekspor ke luar negeri.

Ada beberapa jenis marigold yang dikenal dan dibudidayakan di Indonesia, diantaranya molek kuning (beradaptasi pada ketinggian $300 \mathrm{~m}$ dpl sampai $800 \mathrm{~m} \mathrm{dpl}$, rona (beradaptasi pada ketinggian 600 sampai $800 \mathrm{~m}$ dpl) dan cassanova (beradaptasi pada ketinggian lebih dari 800 $m$ dpl) (Zahir, 2021; SK Mentan No. 078/Kpts/SR.120/D.2.7/8/2013. Namun menurut Priyanka et al. (2013) dalam Beti (2020), marigold termasuk tanaman yang sangat adaptif, dapat tumbuh di dataran rendah sampai dataran tinggi. Nampaknya hal tersebut juga menjadi poin penting yang menjadi pendukung untuk pengembangan bunga marigold di Indonesia.

Faktor lain yang menjadi pendukung pengembangan marigold di Indonesia adalah cara budidayanya yang relatif mudah. Walaupun demikian, berbagai aspek budidaya harus ditempuh untuk mendapatkan kuantitas dan kualitas bunga yang lebih baik.

\section{METODE}

Artikel ini dibuat dengan metode studi literatur, menggunakan sumber dari hasil penelaahan dan hasil-hasil penelitian terdahulu. Hasil penelaahan akan menjadi bahan pula untuk penelitian yang rencananya akan segera dilaksanakan.

\section{BOTANI DAN SYARAT TUMBUH MARIGOLD}

Marigold merupakan anggota dari family Compositae (Asteraceae), dan mempunyai 59 spesies, diantaranya Tagetes erecta, $T$. tenuifolia, T. filifolia, T. lacera, T. lucida, T. minuta, dan T. minuta (Winarto, 2014). Tagetes erecta (African marigolds, American marigolds, atau Mexican marigolds). Species ini merupakan yang paling tinggi, mencapai 90 sampai $120 \mathrm{~cm}$ menghasilkan bunga besar dan banyak. Mereka berasal dari Mexico and Amerika Tengah dan tetap bertahan pada kondisi kekeringan (Farmer's Almanac, 2021).

Tanaman marigold tumbuh tegak setinggi 0,6 sampai 1,3 m. Daun marigold berbentuk menyirip dengan warna hijau gelap dan mempunyai akar tunggang. Bunganya berukuran diameter antara $7 \mathrm{~cm}$ sampai 10 $\mathrm{cm}$, berbentuk bonggol, tunggal atau terkumpul dalam malai, dengan susunan mahkota bunga rangkap yang berwarna putih, kuning, oranye, kuning keemasan atau berwarna ganda (Winarto, 2014).

Marigold serupa tapi tidak sama dengan kenikir sayur (Cosmos caudatus) walaupun di pulau Jawa memang marigold disebut juga kenikir. Morfologi tanaman, seperti batang, daun dan bunga ke dua jenis 
tanaman tersebut hampir sama, tetapi tanaman marigold berbau kurang enak, sedangkan kenikir berbau harum dan dapat dijadikan sayuran.

Sastrapradja (1979) dalam Arini et al. (2015), menyatakan bahwa tanaman kenikir lokal tidak memiliki syarat tumbuh yang terlalu rumit, dapat tumbuh baik di dataran rendah hingga $700 \mathrm{~m}$ dpl. Maccubin dan Tasker (2002) dalam Arini, Respatie, dan Waluyo (2015) menyatakan bahwa kenikir Marigold tumbuh baik pada suhu $18^{\circ}-23^{\circ} \mathrm{C}$ dengan kelembaban $40 \%$ sampai $70 \%$. Tanaman Marigold mampu beradaptasi baik di dataran tinggi dengan ketinggian $800 \mathrm{~m}$ dpl. Trias (2018), mengatakan bahwa Marigold bisa tumbuh sempurna kalau mendapatkan cahaya matahari penuh. Namun demikian apabila cahaya matahari terhalang sampai $20 \%$, masih dapat bertahan.

\section{POTENSI MARIGOLD DALAM MENDUKUNG PENGEMBANGAN PERTANIAN}

Pada saat ini bunga marigold di Indonesia popularitasnya masih kurang. Hanya beberapa daerah saja yang sangat mengenal bunga marigold dan memanfaatkannya terutama dalam upacara keagamaan. Penulis mencoba menelaah berbagai aspek terhadap potensi bunga marigold sebagai salah satu komponen yang mendukung perkembangan pertanian.

\section{Kegunaan Marigold dalam Bidang Kesehatan}

Di luar negeri sudah banyak diteliti tentang marigold ini karena kandungan karotenoidnya. Seperti telah dikemukakan Handelman (2021) dan Seafast Center (2020), bahwa bunga marigold mengandung pigmen karotenoid berwarna kuning seperti karoten (alfa dan beta karoten) dan xantofil (luten dan zeaxantin). Warna kuning pada bunga disebabkan dua pigmen utama yaitu pigmen golongan karotenoid dan flavonoid.

Flavonoid adalah metabolit sekunder dari polifenol, ditemukan secara luas pada tanaman serta makanan dan memiliki berbagai efek bioaktif termasuk anti virus, anti-inflamasi, anti penuaan, antioksidan, kardioprotektif, antidiabetes, anti kanker, (Qinghu Wang et al. 2016, Marzouk, 2016, Vanessa et al. (2014) dalam Arifin dan Ibrahim (2018). Berdasarkan hal tersebut maka bunga marigold mempunyai potensi digunakan sebagai bahan yang dapat mengobati diabetes, kanker, anti penuaan, anti virus.

Studi yang dilakukan Artha et al. (2016) dalam Arini et al. (2015), di daerah Trunyan Bali, menunjukkan bahwa bunga marigold dimanfaatkan sebagai obat herbal, yaitu untuk penyakit gondok. Sedangkan akar dan daunnya digunakan untuk obat kulit bernanah. Sementara itu di India digunakan untuk obat herbal yang menyembuhkan demam, epilepsy, obat perut, kudis, hati, penyakit mata.

Dewasa ini pengobatan tradisional yang menggunakan herbal semakin dicari karena orang sudah sangat khawatir terhadap pengobatan kimia. Oleh karena itu penggunaan bunga marigold sebagai bahan pengobatan menjadi sangat prospektif.

Menurut Zahir (2021), cara mengolah bunga marigold untuk keperluan konsumsi adalah dengan cara mengeringkan bunganya. Kemudian bunga kering tersebut ditumbuk dan diseduh seperti layaknya teh.

Penulis berpendapat bahwa cara pengolahan yang sederhana ini memungkinkan untuk dilakukan oleh berbagai kalangan, misalnya kelompokkelompok tani, kelompok wanita tani atau ibu-ibu rumah tangga yang mengisi kekosongan waktu. Dalam hal ini akan menambah nilai pendapatan dalam skala rumah tangga. Dalam skala yang lebih besar bisa dikembangkan teh marigold dengan 
berbagai cita rasa. Pada dasarnya memang bunga marigold yang berwarna cantik itu, memiliki aroma yang kurang sedap. Seperti dikatakan Marini et al. (2018), bahwa marigold sebagai bunga penghias pekarangan memiliki bau khas yang menyengat sehingga banyak digunakan sebagai tanaman pengusir serangga. Aroma yang kurang sedap ini bila akan dijadikan bahan teh, maka dapat diolah dengan menambahkan berbagai aroma seperti yang ada pada aroma teh masa kini.

\section{Kegunaan Marigold sebagai Refugia}

Yang dimaksud refugia adalah jenis tumbuhan yang dapat mengundang dan menyediakan musuh alami sebagai predator. Tanaman seperti ini berpotensi mengendalikan hama secara alami, yang diyakini lebih aman bagi manusia dan lingkungan. Sebagaimana dikatakan Muhibah dan Leksono (2015) dalam Erdiansyah, Ningrum dan Damanhuri (2018), bahwa pengendalian hama dengan pestisida kimia (sintetik), dapat mengganggu keseimbangan ekosistem sehingga populasi hama akan semakin meningkat. Oleh karena itu lebih aman menggunakan cara alami. Erdiansyah, Ningrum dan Damanhuri (2018), menggunakan tanaman marigold untuk mengurangi populasi arthropoda pada tanaman padi sawah. Hasil penelitiannya menunjukkan bahwa penggunaan tanaman marigold dan kacang hias sebagai refugia, berpengaruh terhadap jumlah anakan produktif, terhadap populasi musuh alami belalang bertanduk panjang. Sejalan dengan pendapat Wardani et al. (2013) dalam Erdiansyah, Ningrum dan Damanhuri (2018), bahwa tanaman refugia pada sekitar lahan pertanian dapat dijadikan habitat alternative bagi banyak serangga berupa predator maupun parasitoid.

Tanaman yang dijadikan sebagai refugia biasanya memiliki warna yang sangat mencolok dan memiliki aroma yang khas. Dikatakan pula oleh Wardana et al. (2017), bahwa bunga marigold memang cocok dijadikan sebagai tanaman refugia karena warna bunganya yang sangat mencolok dan memiliki aroma yang menyengat, sehingga dapat menarik hama maupun musuh alami.

Pada tanaman padi, marigold terbukti mampu menekan intensitas serangan dan populasi hama wereng coklat (Minarni et al., 2018). Selanjutnya penelitian Lestari (2018), juga menunjukkkan kemampuan tanaman marigold menekan intensitas serangan hama ulat bawang (Spodoptera oxygua Hubner). Berdasarkan data-data tersebut maka dapat dikatakan bahwa tanaman marigold mempunyai potensi membantu menekan serangan berbagai macam hama dengan cara yang lebih aman bagi lingkungan.

\section{Kegunaan Tanaman Marigold sebagai Bahan Obat Anti Nyamuk}

Telah disampaikan terdahulu bahwa bunga marigold mengandung metabolit sekunder flavonoid, saponin, tannin dan steroid yang berfungsi sebagai insektisida hayati (Kusmiati, 2011). Telah dibuktikan oleh Wardani et al. (2019), bahwa cairan yang terbuat dari ekstrak bunga marigold dengan konsentrasi $60 \%$ efektif membunuh nyamuk Aedes agepty. Hal lain yang dicoba oleh Marini et al. (2018), adalah membuat lotion yang terbuat dari ekstrak daun marigold untuk anti nyamuk. Efektifitasnya bergantung pada konsentrasi, yaitu konsentrasi ekstrak daun sebesar 30\% dapat bertahan selama 2 jam setelah pengolesan.

Dengan demikian terbukti bahwa metabolit sekunder pada tanaman marigold dapat digunakan sebagai anti nyamuk. Sejalan dengan yang dikatakan Utomo (2010), bahwa metabolit itu dapat bersifat racun kontak, racun pernafasan, serta racun perut pada hewan berbadan lunak, diantaranya nyamuk. 


\section{Kegunaan Marigold sebagai Bunga Potong dan Bunga Taman.}

Tanaman marigold dengan bunga yang berwarna putih, kuning dan orange mencolok memang pantas untuk dijadikan bunga potong maupun bunga taman. Apalagi dewasa ini banyak orang menyukai tempattempat rekreasi yang menampilkan bunga berwarna cantik menyolok sebagai background berfoto. Bahkan untuk karangan bunga papan sudah banyak digunakan. Oleh karena itu marigold mempunyai poteni untuk dikembangkan.

Penyebaran marigold memang seolah terjadi stagnasi karena banyak bunga lain bermunculan. Padahal di jaman dulu, bunga marigold ini sangat akrab dengan masyarakat, bahkan hampir di setiap pekarangan rumah terdapat berbagai jenis kenikir, antara lain marigold.

Seiring dengan perkembangan ilmu pengetahuan, maka tanaman yang semula tidak diperhatikan, akan menjadi potensial dikembangkan di masa depan. Hal ini dapat terjadi pada bunga marigold disebabkan temuan-temuan yang mendukungnya.

Selain dari aneka kegunaannya, ada beberapa faktor yang akan menjadi bahan pertimbangan :

1. Marigold termasuk tanaman yang tidak sulit dibudidayakan. Indonesia mempunyai wilayah yang cocok untuk ditanami marigold, baik di dataran tinggi maupun dataran rendah.

2. Potensi hasil per hektar cukup tinggi yaitu 24 sampai $30 \mathrm{t} \mathrm{ha}^{-1}$ (PT. East West Seed Indonesia).

3. Umur panen yang relatif genjah, yaitu 39-50 hari (varietas Molek Kuning), 35 sampai 45 hari (Golden Bloom F1), 45 sampai 50 hari (varietas Rona (Zahir, 2021 ; PT. East West Seed Indonesia)

4. Masa panen yang panjang yang berarti memperpanjang masa keindahan taman, masa kegunaan sebagai tanaman repelen, masa kegunaan sebagai anti nyamuk.
5. Penanaman bisa menggunakan benih sendiri, bahkan bisa secara khusus pembudidayaaan untuk menghasilkan benih secara komersial.

\section{SIMPULAN}

1. Marigold mempunyai berbagai macam kegunaan, mudah dibudidayakan, secara ekonomis dan ekologis menguntungkan.

2. Marigold bisa dijadikan ladang usaha skala rumahan maupun skala besar.

\section{SARAN}

Perlu dilakukan penelitian terutama yang berkaitan dengan :

1. Peningkatan hasil per satuan luas

2. Peningkatan kandungan karoten pada bunga

\section{DAFTAR PUSTAKA}

Arini, Nindya, Dyah Weny Respatie, dan Sriyanto Waluyo. 2015. Pengaruh Takaran SP36 terhadap Pertumbuhan, Hasil dan Kadar Karotena Bunga Cosmos sulphureus Cav. dan Tagetes erecta L. di Dataran Rendah. Vegetalika. Vol. 4 No 1, 2015 : 1-14.

Arifin, Bustanul, Sanusi Ibrahim. 2018. Struktur, Bioaktivitas Dan Anti oksidan Flavonoid. Jurnal Zarah, Vol. 6 No. 1 (2018), Hal: 21-29.

Artha, Pt Y G, Saptasari, M., dan S. Mahanal. 2016. Studi Etnibotani Masyarakat Lokal Desa Truyan Propinsi Bali untuk mata kulaih di Perguruan Tinggi. Prosiding Seminar Nasional II, Universitas Muhammadiyah Malang. Hal 44-48.

Beti, Jajuk Aneka. 2020. Marigold (Tagetes erecta L.) Tanaman Hias Potensial Multiguna. Prosiding Seminar Nasional. Pertanian Peternakan 
Terpadu ke-3. ISBN : 978-602-607822-3.

Erdiansyah, Iqbal, Dwi Rahmawati Kusuma Ningrum, dan Damanhuri. 2018. Pemanfaatan Tanaman Bunga Marigold dan Kacang Hias terhadap Populasi Arthropoda pada Tanaman Padi Sawah. Agriprima, Journal of Applied Agricultural Sciences. Online version:https//agriprima. olije.ac.id Vol.2, No.2, Hal 117-125.

Handelman, G.J. 2001. The evolving role carotenoids in human biochemistry. Nutrition 17: 818-822.

Kumar, Parveen, Arvinder Singh, Nomita Laishram, RK Pandey, Sheetal Dogra, M.Iqbal Jaelani, dan BK Sinha. The Effects of Plant Growth Regulator on Quality Flower and Seed Production of Marigold (Tagetes erecta L). Bangladesh J. Bot. 49(3):567-577 (September).

Kusmiati. 2011. Daya antioksidan senyawa Lutein dari Bunga Kenikir (Tagetes erecta L) terhadap Tikus Putih yang Mengalami Hiperkolesteolemik. Pusat Penelitian Bioteknologi-LIPI, Bogor.

Lestari, R.P. 2018. Pengaruh Manipulasi habitat pada lahan Bawang Merah (Allium ascalonicum) dengan Teknik Border Crop Tanaman Berbunga terhadap Serangan Hama Ulat Bawang (Spodoptera oxygua Hubner) dan populasi Musuh Alami. Skripsi. Universitas Jember.

Zahir, Fakhri. 2021. Cara menanam Bunga Marigold yang Benar. https://kutanam.com/cara- menanambunga-marigold/.

Marini, Tanwirotun Ni'mah, Vivin Mahdalena, Rahayu Hasti Komariah, dan Hotnida Sitorus. Potensi Ekstrak Daun Marigold (Tagetes erecta L.) sebagai Larvasida terhadap Larva Aedes aegypti di Laboratorium. Balai Litbang Kesehatan Baturaja, Badan Litbang
Kesehatan, Kementerian Kesehatan RI. https://doi.org/10.22435/vektorp.v 12i2.898. Diunduh 1 April 2021.

Nata, I Nyoman Indra Bayu, I Putu Dharma, dan I Ketut Arsa Wijaya. Pengaruh pemberian Berbagai Macam Pupuk terhadap Pertumbuhan dan Hasil Gumitir (Tagetes erecta L.). Jurnal Agroteknologi Tropika. ISSN:23016515 Vol. 9, No. 2, April 2020 https:// ojs. unud .ac.id/index.php/JAT.

PT. East West Seed Indonesia. Cap Panah merah. 2018. Rekomendasi Dataran. Desa Bneteng Kec. Campaka Purwakarta.

Seafast Center. 2012. Kuning-MerahKarotenoid. http://seafast.ipb.ac.id. Diunduh 15 April 2021.

Setiawan. 2017. Jadi Pelengkap Canang di Bali, Potensi Bisnis Bunga Marigold. Kompas.com.01/07/ 2017.

Trias. 2018. Menanam Marigold, Pemupukan dan perawatan. https://ilmu budidaya.com/tips-menanam-marigold. Diunduh 1 April 2021.

Utomo, M. 2010. Pengaruh Jumlah Air yang Ditambahkan pada Kemasan Serbuk Bunga Sukun (Artocarpus communis) sebagai Pengganti Isi Ulang Obat Nyamuk Elektrik terhadap Lama Waktu Efektif Daya Bunuh.

Wahyu. 2019. Cara Budidaya Marigold. https://petaniberdasi-media-blog spotcom/2019/01/cara- budidayabunga-marigold-lengkap.html.

Wardana, R., Erdiyansyah, I.,I dan Putri, S.U. 2017. Presistensi Hama (Pemanfaatan Tanaman Refugia Sebagai Sistem Pengendali Hama Padi) pada Kelompok Tani Suren Jaya 01, Kecamatan Ledokombo. In Seminar Nasional Hasil Pengabdian Kepada Masyarakat (pp.233-237). 
Wardani, IGAAK, Megawati, F., Santoso, P., dan IPT. Suwantara. 2019. Efektifitas Sediaan Cair Elektrik dari ekstrak Bunga Gumitir (Tagetes erecta L.) sebagai Anti Nyamuk Aedes aegepti. J. Ilmiah Medicamento 5(1). Hal. 1-5.

Winarto, L. 2010. Tagetes Berguna Bagi Kita. Deptan. BPTP, Sumatera Utara.http://sumut.litbang. deptan. go.id/ind/index.php/component/ ontent/article/ 15benih/53-tageteserecta-berguna-bagi-kita.

Winarto L. 2014. Tagetes Erecta. sumut.litbang.deptan.go.id. Diunduh 1 Agustus 2020. 